\title{
Soothing effect of virgin coriander seed oil on sensitive skin ${ }^{\text {th }}$
}

\author{
Catherine Kern ${ }^{*}$, Christian Gombert, Alicia Roso and Christine Garcia \\ Seppic, Paris La Défense, 50, boulevard National-CS 90020, 92257 La Garenne Colombes Cedex, France
}

Received 27 May 2020 - Accepted 13 August 2020

\begin{abstract}
Sensitive skin is a common condition that concerns many people in the world. This syndrome is defined by the occurrence of unpleasant sensations such as stinging and burning in response to stimuli that normally should not provoke such sensations. The main hypothesis attributed to the occurrence of sensitive skin is the disruption of the epidermal barrier and a greater penetration of substances such as irritants. In keratinocytes, the NF- $\mathrm{\kappa B}$ pathway, which plays an important role in orchestrating inflammatory responses, is then activated. Regulation of this activation is a key issue to control inflammation. Due to the wide variety of sensory symptoms, neurosensory dysfunction also represents a mechanism to be considered. Some of the cutaneous nerve endings express TRPA1, a sensor of skin barrier insult, which is involved in a variety of physiological or cellular processes including nociception, itch and neurogenic inflammation. Regulation of such sensor activation is also an issue to consider to control neurosensory dysfunction. Coriander seed oil is a $100 \%$ virgin oil of coriander seeds and boasts a unique composition of fatty acids. The soothing effect of coriander seed oil on sensitive skins was investigated by studying its capacity to regulate NF-кB and TRPA1 activation. Coriander seed oil allowed the regulation of NF-KB activation induced by TNF- $\alpha$ in an in vitro model of inflammation in keratinocytes. It also regulated the activation of TRPA1 induced by allyl isothiocyanate in an in vitro model of keratinocytes-neurons co-culture. These results are in favor of a soothing effect of coriander seed oil.
\end{abstract}

Keywords: sensitive skin / coriander seed oil / soothing / inflammation / nociception

Résumé - Effet apaisant de l'huile vierge de graines de coriandre chez les peaux sensibles. La peau sensible est un syndrome courant qui concerne de nombreuses personnes dans le monde. Elle est définie par l'apparition de sensations désagréables telles que des picotements et des brûlures en réponse à des stimuli qui normalement ne devraient pas provoquer de telles sensations. La principale hypothèse associée à l'apparition de la peau sensible est la perturbation de la barrière épidermique, et une plus grande pénétration de substances comme les irritants. Dans les kératinocytes, la voie NF- $\mathrm{BB}$, qui joue un rôle important dans l'orchestration des réponses inflammatoires, est alors activée. Sa régulation est clé pour contrôler cette réponse inflammatoire. En raison des symptômes sensoriels concomitants, un dysfonctionnement neurosensoriel est également un mécanisme associé aux peaux sensibles. Certaines terminaisons nerveuses dans la peau expriment entre autres le récepteur TRPA1 qui détecte les agressions de la barrière cutanée et est impliqué dans une variété de processus physiologiques et cellulaires, dont la nociception, les démangeaisons et l'inflammation neurogénique. La régulation de son activation est elle aussi à considérer pour contrôler le dysfonctionnement neurosensoriel. L'huile de graines de coriandre est une huile $100 \%$ vierge qui possède une composition unique en acides gras. L'effet apaisant de l'huile de graines de coriandre sur les peaux sensibles a été étudié pour sa capacité à réguler l'activation de NF- $\mathrm{BB}$ et de TRPA1. Cette huile permet en effet de réguler l'activation de NF- $\kappa \mathrm{B}$ induite par le TNF- $\alpha$ dans un modèle in vitro d'inflammation des kératinocytes. Elle régule aussi l'activation de TRPA1 induite par l'isothiocyanate d'allyle dans un modèle in vitro de co-culture de kératinocytes-neurones. Ces résultats sont en faveur d'un effet apaisant de l'huile de graines de coriandre.

Mots clés : peau sensible / huile de graines de coriandre / apaisant / inflammation / nociception

\footnotetext{
H7 Contribution to the Topical Issue "Lipids and Cosmetics / Lipides

et cosmétiques".

*Correspondence: catherine.kern@airliquide.com
} 


\section{Introduction on sensitive skin}

\subsection{Definition and overview}

Sensitive or reactive skin is a common condition that concerns approximately $50 \%$ of people. $60 \%$ women and $40 \%$ men report having reactive skin, and the prevalence can also vary depending on the country (Misery et al., 2017). Epidemiological studies suggest that the prevalence of sensitive skins increases although the methods used for diagnosis have evolved with time (Misery et al., 2016). Sensitive skin refers to a sensory reaction triggered by contactors and/or environmental factors, usually without visible clinical manifestation (Duarte et al., 2017). Recently, a consensus definition was proposed by a working group (special interest group on sensitive skin of the International Forum for the Study of Itch) as: "A syndrome defined by the occurrence of unpleasant sensations (stinging, burning, pain, pruritus, and tingling sensations) in response to stimuli that normally should not provoke such sensations. These unpleasant sensations cannot be explained by lesions attributable to any skin disease. The skin can appear normal or be accompanied by erythema. Sensitive skin can affect all body locations, especially the face" (Misery et al., 2017). While the face is the most common site of sensitive skin, other parts of the body are also affected, such as hands, scalp, feet, neck, torso and back (Saint-Martory et al., 2008). Possible synonyms for this condition are hypersensitivity, (hyper)reactivity, sensitivity, intolerance or skin irritation. Described sensations can vary largely: pain, pruritus, burning, tingling, prickling, pungency, thickening or dryness of the skin, and may or may not be accompanied by signs such as redness, mild erythema, telangiectasias, xerosis, desquamation, or urticaria.

Environmental factors such as UV irradiation, air pollution, climate conditions (temperature, humidity, wind, sun exposure...), as well as lifestyle factors, such as cosmetic usage, diet and alcohol consumption, and physiological factors, such as stress or endogenous hormones, have been reported to induce or worsen the symptoms of sensitive skin (Misery et al., 2009; Duarte et al., 2017).

The main hypothesis attributed to the occurrence of sensitive skin is the increase in the permeability of the stratum corneum, leading to disruption of the epidermal barrier and a greater penetration of substances such as irritants or allergens and also increased water loss. Due to the wide variety of sensory symptoms such as burning, tingling, stinging, pain and sometimes even itching, neurosensory dysfunction in the skin also represents one of the pathomechanisms of sensitive skin (Ständer et al., 2009; Misery et al., 2016; Duarte et al., 2017 and Fig. 1).

\subsection{Inflammation in sensitive skin}

When irritant substances penetrate the epidermis, they first are in contact with the keratinocytes which react and promote an inflammatory response by increasing the production and the release of various soluble molecules, such as cytokines (such as IL-1, IL-6 and TNF- $\alpha$ ), chemokines (such as IL-8) and antimicrobial peptides (such as defensins and cathelicidins) (Boxman et al., 1996; Duarte et al., 2017). The Nuclear

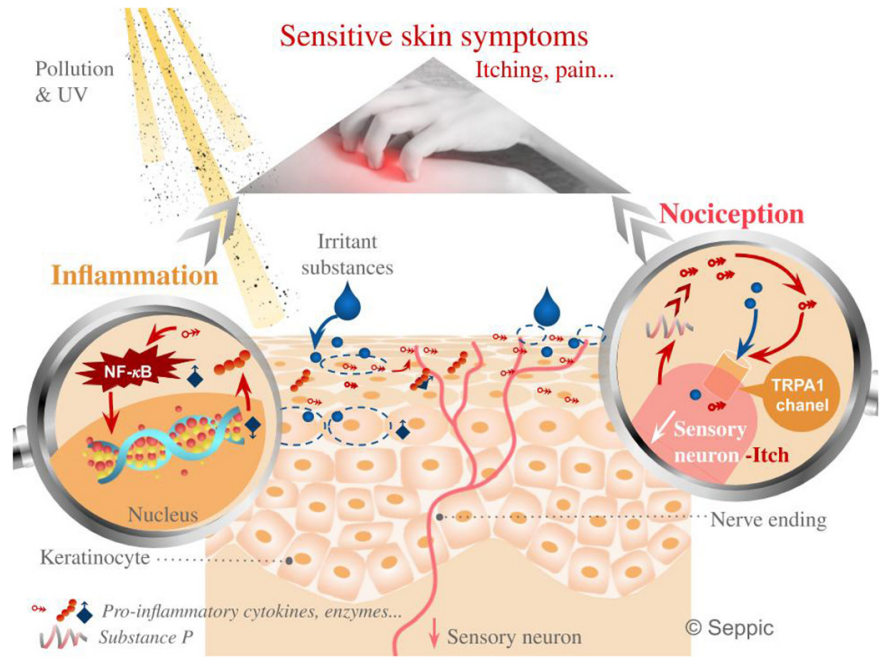

Fig. 1. Biological mechanisms underlying sensitive skin (Ständer et al., 2009; Misery et al., 2016; Duarte et al., 2017).

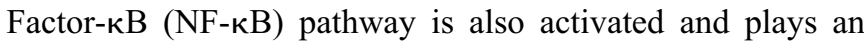
important role in orchestrating and regulating inflammatory and immune responses (Sur et al., 2008). In normal conditions, $\mathrm{NF}-\kappa \mathrm{B}$ proteins are kept in the cytoplasm, bound to the IкB proteins. In response to inflammation/stress stimuli (such as pro-inflammatory cytokines, reactive oxygen species, UV,

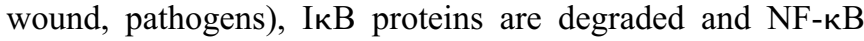
translocates to the nucleus and induces the production of proinflammatory mediators such as chemokines, proinflammatory cytokines, adhesion molecules as well as inducible proinflammatory enzymes which can exacerbate and perpetuate the inflammatory process. On the other side, the blockage of $\mathrm{NF}-\kappa \mathrm{B}$ pathway also generates an inflammatory response through other pathways (Sur et al., 2008). Skin homeostasis thus requires a balanced NF-кB pathway. Deregulated inflammatory responses can cause excessive or long-lasting tissue damages, contributing to the development of acute or chronic inflammation. A balance in NF- $\mathrm{kB}$ activation can then be a key issue to control inflammation and homeostasis of skin.

\subsection{Neurosensory dysfunction in sensitive skin}

The altered sensations in individuals with sensitive skin (burning, tingling, stinging, pain, itching...) can result from an insufficient protection of cutaneous nerve endings due to impaired epidermal barrier integrity or a functional hyperreactivity of cutaneous nerves. Cutaneous nerve fibres such as unmyelinated $\mathrm{C}$ fibres mediating pain, itch and warmth are equipped with sensory neuroreceptors such as transient receptor potential channels (TRP). Notably, members of the TRP family are known to induce pain, burning and itch in sensitive skin. Since sensitive skin is induced by various environmental factors, including UV light, variation of temperature and air pollution, the activation of TRP channels represent a mechanism by which external stimuli can be transferred to individuals with sensitive skin (Ständer et al., 2009; Misery et al., 2016).

More particularly, the skin free endings (essentially C-type peptidergic unmyelinated fibers) possess ankyrin receptor 
TRPA1 (Transient Receptor Potential Ankyrin 1 channel), a nociceptive cationic (mainly $\mathrm{Ca}^{2+}$ ) channel. TRPA1 is also expressed in the basal keratinocytes. A variety of exogenous and endogenous activators or sensitizers of TRPA1 have been identified such as cold sensation, mustard oil compounds (for example AITC-allyl isothiocyanate), environmental pollutants, reactive oxygen species, bradykinin or cytokines (Gouin et al., 2017). TRPA 1 is involved in a variety of physiological or cellular processes in humans including nociception, especially in response to chemical irritants, itch, neurogenic inflammation and thermosensation (Moore et al., 2018). TRPA1 is also a major sensor of skin barrier insult (Mollanazar et al., 2016): it is required for acute histamine-independent itch, as well as for chronic itch. TRPA1 is implicated in the itch-scratch cycle that can arise in dry skin (Wilson et al., 2013) and is involved in cutaneous neurogenic inflammation and its potentiation by enhancing cellular responses (Bautista et al., 2013; Gouin et al., 2017).

\section{Ecodesigned coriander seed oil as a new ingredient dedicated to sensitive skin}

\subsection{Plant oils and skin}

Beneficial influence of plant oils on skin is widely recognized in cosmetology and, more globally, on the human body by medicine, making them good candidates for a comprehensive in and out approach to wellness and beauty. Composed of a combination of triglycerides, their properties can vary a lot according to their fatty acids composition, as well as other lipophilic components such as vitamins and phytosterols. As an illustration of skin benefits of seed oils when used as dietary supplement, Bamford et al. (2013) performed a meta-analysis on clinical studies looking at the effect of primrose and borage oils on atopic eczema and identified 19 studies on the first one and 9 studies on the second one, however without showing positive effect on these oils on eczema. Hemp seed oil improved skin dryness and itching sensations in atopic dermatitis (Callaway et al., 2005). Supplementation of flaxseed oil showed evidence of reduced skin sensitivity generated by nicotinate irritation on Western women (Neukam et al., 2011). Benefits of topical application of seed oils (from olive, olive pomace, sunflower, coconut, safflower, argan, soybean, peanut, sesame, avocado, borage, jojoba, oat, pomegranate, almond, bitter apricot, rose hip, chamomile and shea) were also reviewed by Lin et al. (2017), showing promising and different effects according to their composition. No study was identified on skin benefits of coriander seed oil.

\subsection{Coriander seed oil}

Coriandrum sativum $L$. is an annual herb from the Apiaceae (Umbelliferae) family that originates from the Near East and Mediterranean area. Coriander is well known as a medicinal herb and has been shown to exhibit antioxidant (Wangensteen et al., 2004), antimicrobial (Rattanachaikunsopon and Phumkhachorn, 2010) and anti-inflammatory activities (Reuter et al., 2008).

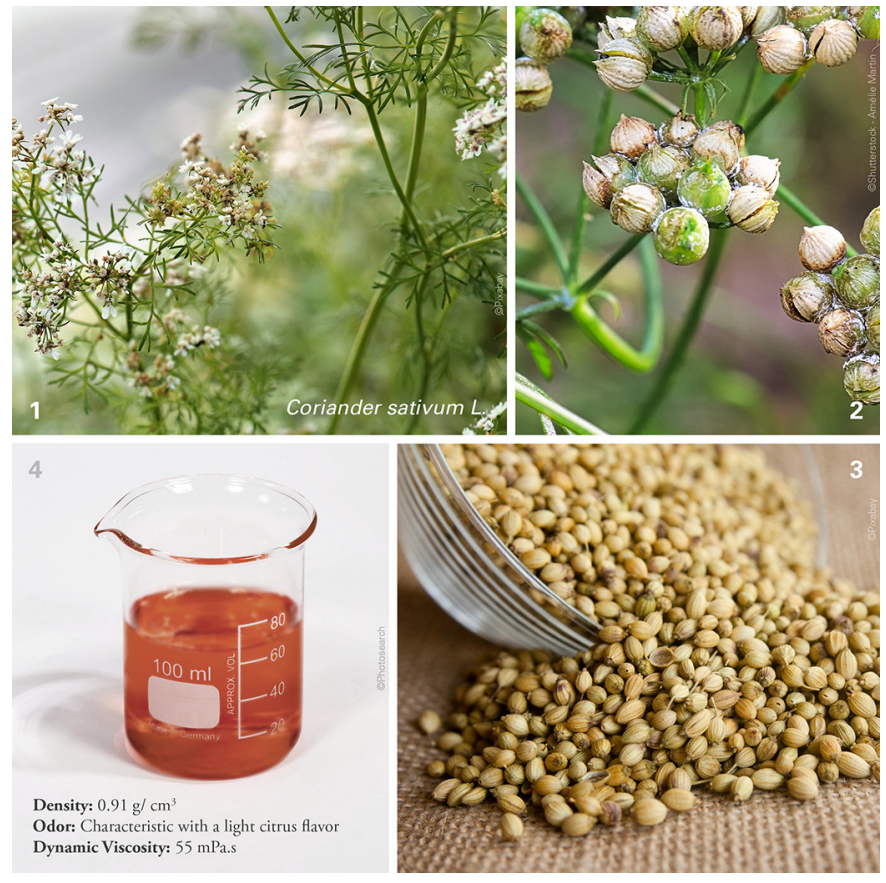

Fig. 2. Coriander seed oil sourcing and characteristics.

Coriander seed oil is a $100 \%$ virgin oil of coriander seeds (Fig. 2), locally sourced and cultured in South West of France. The oil is obtained by mechanical pressing of the fruits using twin-screw extrusion technology, a gentle eco-extraction process without solvent to ensure the protection of the bioactive compounds, the protection of the environment and the safety of the product (Uitterhaegen et al., 2015).

Standardized fatty acids composition of the virgin coriander oil is unique, containing 60 to $75 \%$ of petroselinic acid $(\mathrm{C} 18: 1 \mathrm{n}-12)$ as the major component (see comparison with examples of other plant oils used for in and out benefits in Tab. 1). Petroselinic acid is a uncommon monounsaturated omega-12 positional isomer of oleic acid, with a rare 6-position of the double bond mainly found in the seeds from Apiaceae crops (Fig. 3). The fatty acid has already been shown to exhibit some attractive properties such as anti-aging and antiinflammatory activity. It has already been demonstrated that petroselinic acid can inhibit the production of metabolites of arachidonic acid and/or reduces the formation of intracellular adhesion molecules (Alaluf et al., 2002).

Linoleic acid and its derivatives, also present at a large amount, play a central role in the structure and function of the stratum corneum permeability barrier. Linoleic acid is the most abundant fatty acid in the epidermis. Importantly, it is also the precursor to ceramides, a major component of the extracellular lipid matrix that forms the stratum corneum permeability barrier (McCusker and Grant-Kels, 2010).

Coriander seed oil is also a natural source of phytosterols and tocols (Uitterhaegen et al., 2016). Phytosterols and more particularly, $\beta$-sitosterol, the most abundant of them, are known for having anti-inflammatory action (Gupta et al., 1980; Bouic, 2001). Tocols, i.e. tocopherols and tocotrienols, are fatsoluble vitamin $\mathrm{E}$ isomers that can protect the oil from oxidative reactions. Tocols are also known to have a great antioxidant capacity, protecting the skin by scavenging free 
Table 1. Example of major fatty acid compositions of plant oils.

\begin{tabular}{|l|c|c|c|c|c|c|c|c|c|c|}
\hline $\begin{array}{l}\text { Main fatty } \\
\text { acids } \\
\text { (\%w:w) }\end{array}$ & Palmitic & Palmitoleic & Stearic & Oleic & Petroselinic & Linoleic & $\alpha$-Linolenic & $\gamma$-Linolenic & Stearidonic & Eicosenic \\
\cline { 2 - 11 } & $\mathrm{C} 16: 0$ & $\mathrm{C} 16: 1$ & $\mathrm{C} 18: 0$ & $\mathrm{C} 18: 1$ & $\mathrm{C} 18: 1$ & $\mathrm{C} 18: 2$ & $\mathrm{C} 18: 3$ & $\mathrm{C} 18: 3$ & $\mathrm{C} 18: 4$ & $\mathrm{C} 20: 1$ \\
\hline Omega family & & 7 & & 9 & 12 & 6 & 3 & 6 & 3 & 9 \\
\hline Borage & $6-12$ & & $2-5$ & $10-20$ & & $30-40$ & $15-25$ & & & $0-5$ \\
\hline $\begin{array}{l}\text { Blackcurrant } \\
\text { seed }\end{array}$ & & & & & & 50 & $10-15$ & $15-20$ & & \\
\hline $\begin{array}{l}\text { Coriander seed } \\
\text { oil }\end{array}$ & $2-5$ & & $0-1.5$ & $8-15$ & $60-75$ & $12-19$ & $0-1$ & & $2-5$ & \\
\hline Cranberry & 5.6 & & & 23 & & 37 & 33 & & & \\
\hline Flaxseed & $3-8$ & & $2-6$ & $10-20$ & & $10-18$ & $45-65$ & & & \\
\hline Grape seed & $5-10$ & & $3-5$ & $12-26$ & & $58-77$ & & & & \\
\hline Hemp & $5-12$ & & $1-4.5$ & $10-16$ & & $45-65$ & $14-30$ & $0-3$ & & $0-1$ \\
\hline Nigella sativa & $6-12.5$ & $16-25$ & $1.5-8$ & $15-24$ & & $25-55.5$ & & & & $0-0.3$ \\
\hline Primrose seed & $5.5-10$ & & $1.5-3$ & $2-10$ & & $66-78$ & & $2-11$ & & \\
\hline Pumpkin seed & 13 & & 6 & 38 & & 42 & & & & \\
\hline Safflower & $4-9$ & & & $72-80$ & & $12-16$ & $<0.5$ & & & \\
\hline
\end{tabular}

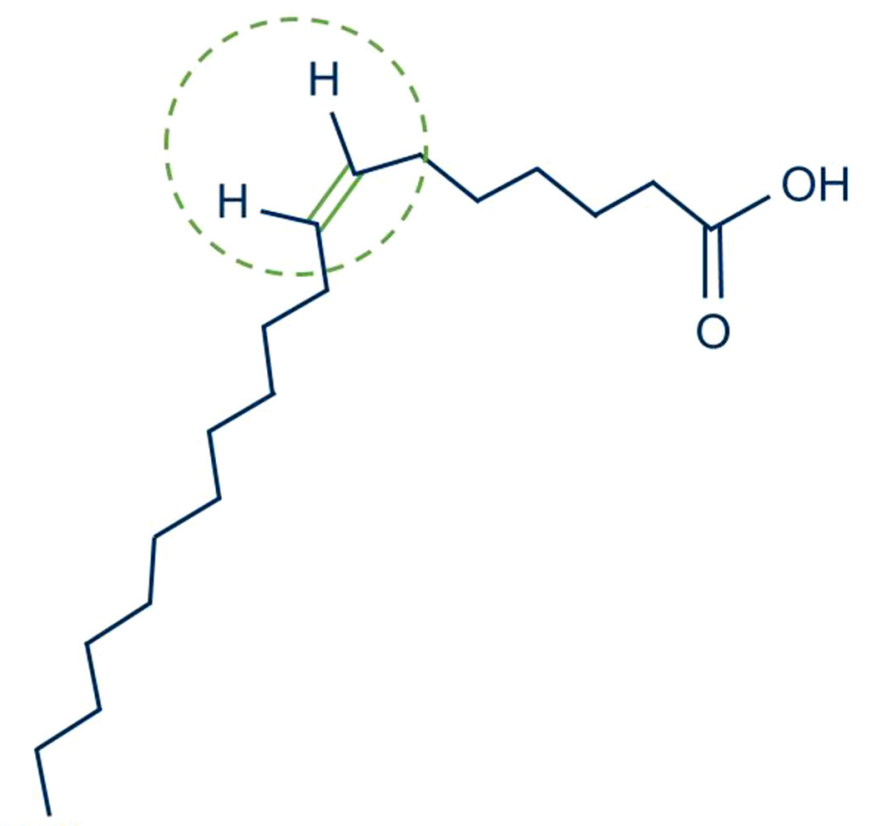

\section{$\mathrm{CH} 3$}

Fig. 3. Chemical structure of petroselinic acid.

radicals, stabilizing the membranes of cells, reducing the number of apoptotic cells, and minimizing the activation of NF-кB (Souyoul et al., 2018).

Considering coriander seed oil original composition, as well as the effects reported for some of its well known compounds, the objective of this study was to evaluate the effect of coriander seed oil (CSO) in vitro, modelling the

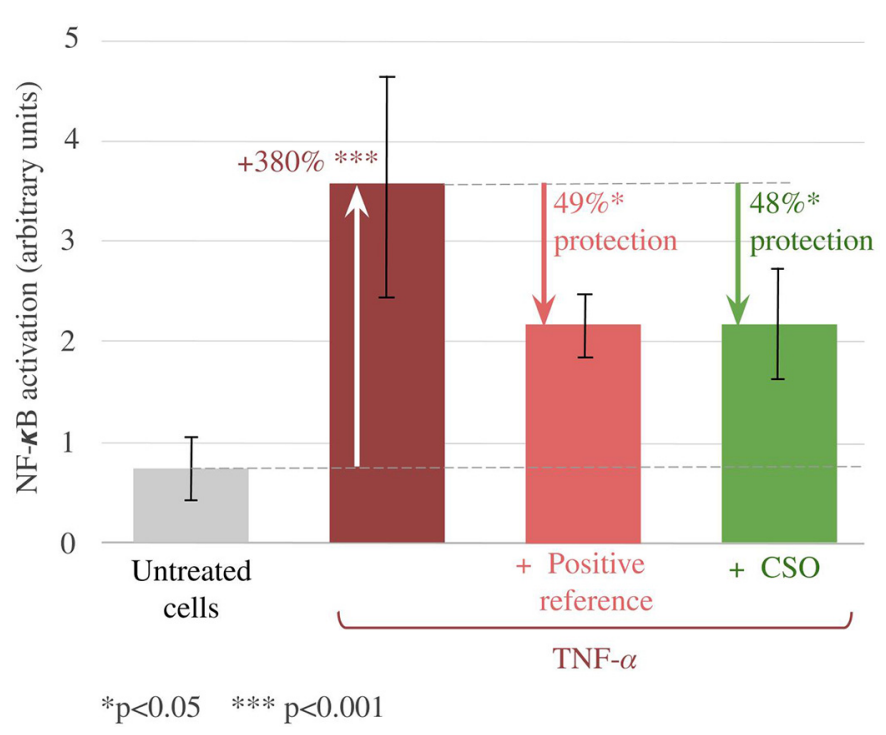

Fig. 4. Activation of NF-кB following stimulation with TNF- $\alpha$.

main components of sensitive skin: inflammation and nociception described above. The effect of CSO was followed with its capacity to regulate NF- $\mathrm{B}$ and TRPA1 activation.

\section{Materials and methods}

\subsection{Study of NF-кB activation in keratinocytes}

The soothing effect of CSO was assessed in an in vitro model of inflammation. 


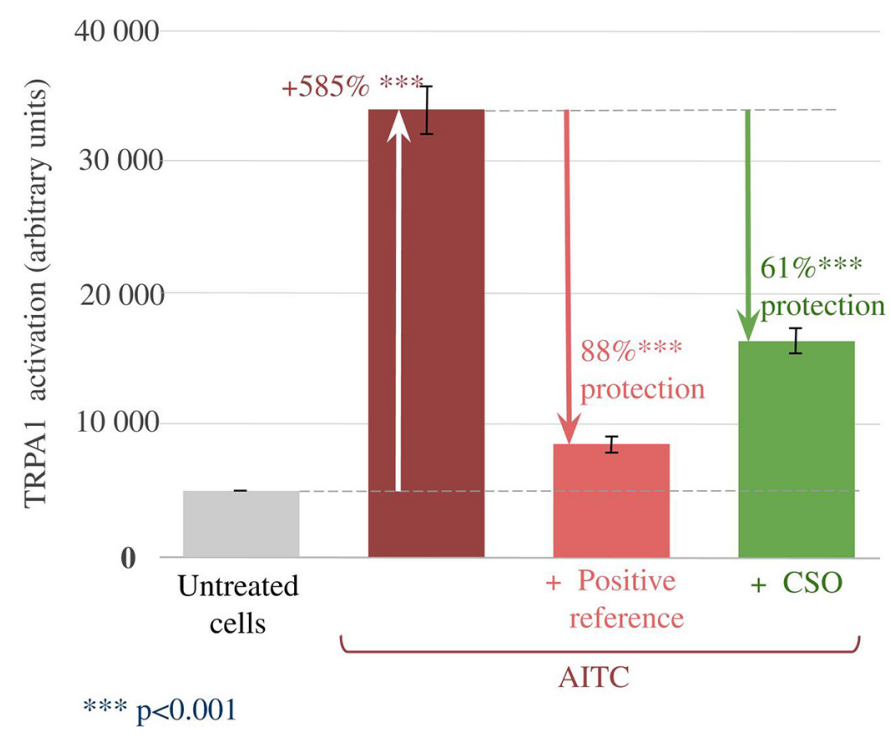

Fig. 5. Activation of TRPA1 following stimulation with AITC.

HaCaT human keratinocytes cell line was transfected with luciferase reporter gene or control gene under the control of a promoter recognized by the transcription factor NF-кB.

$\mathrm{HaCaT}$ cells were cultivated during 5 days at $37^{\circ} \mathrm{C}$ in a humidified incubator under a $5 \% \mathrm{CO}_{2} 95 \%$ air atmosphere. Then CSO $0.0001 \%(\mathrm{v} / \mathrm{v})$ or positive reference (a cellpermeable quinazoline compound as NF- $\mathrm{B}$ activation inhibitor, $\mathrm{C}_{22} \mathrm{H}_{20} \mathrm{~N}_{4} \mathrm{O}$ ) $0.1 \mu \mathrm{M}$ were added to the culture medium. After $24 \mathrm{~h}$, the medium was replaced by an inflammatory stress, TNF- $\alpha 0.075 \mathrm{ng} / \mathrm{mL}$, and once again tested products, for additional $16 \mathrm{~h}$. Then, luciferase was dosed in supernatants, by adding luciferase substrate and measuring the emitted light. Proteins were dosed in cell lysates with a specific kit using the bicinchoninic acid method to normalise results (luciferase activity/quantity of proteins).

All experimental conditions were performed in at least four replicates. For each condition, the mean and the standard deviation were calculated and the value was standardised with value obtained for cells containing control reporter gene.

Percentage of stimulation for TNF- $\alpha$ treatment was calculated by mean $(\mathrm{TNF} \alpha$-stimulated cells $) \times 100 /$ mean (untreated cells). Percentage of protection was calculated with the following formula: [mean (condition) - mean (TNF $\alpha-$ stimulated cells) $] \times 100 /[$ mean (untreated cells) - mean (TNF $\alpha$-stimulated cells)].

Statistical significance between conditions was assessed using a two-tailed, unpaired Student t-test, with $p<0.05$ being considered significant.

\subsection{Study of TRPA1 activation in keratinocytes- neurons co-culture}

The soothing effect of CSO was assessed with an in vitro assay on keratinocytes-neurons co-culture model in which was evaluated TRPA1 activation by detecting variation of intracellular concentration of calcium.

Sensitive neurons were derived from human induced pluripotent stem cells. Cells were cultivated at $37^{\circ} \mathrm{C}$ in a humidified incubator under a $5 \% \quad \mathrm{CO}_{2} \quad 95 \%$ air atmosphere until maturation. Then keratinocytes from an adult donor were seeded with sensitive neurons for 19 days of co-culture. CSO $0.001 \%(\mathrm{v} / \mathrm{v})$ or positive reference ( $\mathrm{HC} 30031, \mathrm{C}_{18} \mathrm{H}_{21} \mathrm{~N}_{5} \mathrm{O}_{3}$ ) $10 \mu \mathrm{M}$ were added, together with the fluorescent probe Fluo-4 AM which detects variation of intracellular concentration of calcium. After incubation, cells were washed, incubated once again with CSO or positive reference and immediately observed by epi-fluorescence in microscopy. Then they were stimulated with AITC and the fluorescence level of activated neurons was followed.

Experiments were done by 6 wells per condition. Mean and SEM (standard error of the mean) of fluorescence increase were analysed and compared with non-activated control and activated control without tested products.

Percentage of stimulation for AITC treatment was calculated by mean (AITC - stimulated cells $) \times 100 /$ mean (untreated cells). Percentage of protection was calculated with the following formula: [mean (condition)- mean (AITCstimulated cells) $] \times 100 /[$ mean (untreated cells) - mean (AITC-stimulated cells)].

Statistical analysis was done by One Way ANOVA test, with $p<0.05$ being considered significant.

\section{Results}

\subsection{CSO regulates NF-kB activation in inflammatory conditions in keratinocytes}

TNF- $\alpha 0.075 \mathrm{ng} / \mathrm{mL}$ induced a significant increase in NF$\kappa \mathrm{B}$ activation $(+380 \%$ vs. untreated cells, $p<0.001)$ in keratinocytes.

$\mathrm{NF}-\kappa \mathrm{B}$ activator inhibitor significantly protected keratinocytes from NF-кB activation by $49 \%(p<0.05)$. CSO $0.0001 \%$ also allowed a significant protection of keratinocytes from NF- $\mathrm{BB}$ activation by $48 \%(p<0.05)$.

These data show that CSO was able to regulate NF- $\mathrm{B}$ activation in inflammatory conditions in keratinocytes, and then can contribute to regulate inflammation by this way (Fig. 4).

\subsection{CSO regulates TRPA1 activation in keratinocytes- neurons co-culture}

AITC $1 \mathrm{mM}$ induced a huge and significant increase in TRPA1 activation $(+585 \%$ vs. untreated cells, $p<0.001)$ in keratinocytes-neurons co-culture.

HC30031 at $10 \mu \mathrm{M}$ significantly protected keratinocytesneurons co-culture from TRPA1 activation by $88 \%$ $(p<0.001)$. CSO $0.001 \%$ also allowed a significant protection of keratinocytes-neurons co-culture from TRPA1 activation by $61 \%(p<0.001)$.

These data show that CSO was able to regulate TRPA1 activation in keratinocytes-neurons culture (Fig. 5).

\section{Conclusions and discussion}

Two main mechanisms can support sensitive skin: a disruption of the epidermal barrier leading to an increased inflammation and a neurosensory dysfunction leading to the symptoms such as burning, tingling, stinging, pain, itching... 


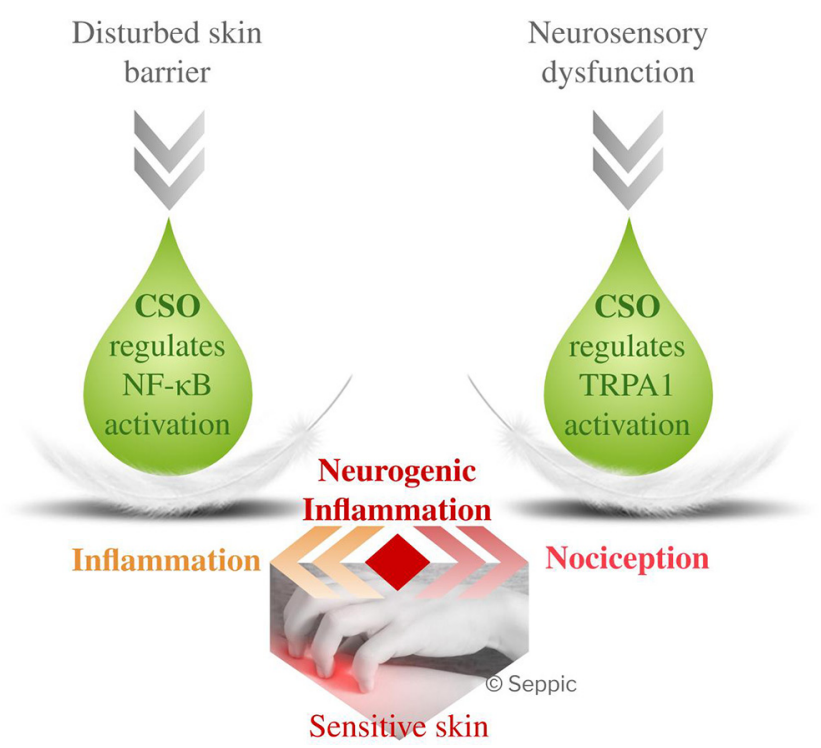

Fig. 6. Summary of CSO biological action.

Data obtained with CSO showed that it can regulate NF- $\mathrm{B}$ activation, and thereby inflammation induced by disturbed skin barrier in sensitive skin. CSO can also regulate TRPA1 activation, and thus sensations of nociception such as itching, tingling... Thus it is considered a promising soothing ingredient for sensitive and reactive skins (Fig. 6).

As previously described in the introduction, coriander is already known to have some beneficial effects such as antiinflammatory properties. Some of the components of its oil are also recognized as beneficial, especially petroselinic acid, which is furthermore a fatty acid rarely found in plant oils. Coriander seed oil also contains linoleic acid, phytosterols and tocopherols which can contribute to the protective effect observed. But to our knowledge, it is the first time that the whole coriander seed oil was tested on skin models and showed a beneficial effect on inflammation and nociception. Additional investigations are required to identify the precise mode of action of the components of coriander seed oil.

Regulation of NF-кB and TRPA1 pathways are linked by cutaneous neurogenic inflammation. Pro-inflammatory mediators produced by keratinocytes such as cytokines can stimulate TRPA1 which can in turn also induce the production of pro-inflammatory neurotransmitters. Moreover, the activation of TRPA1 results in the local cutaneous release of neuropeptides such as substance $P$, which subsequently activates different cell types in the skin such as keratinocytes which release proinflammatory cytokines and chemokines, resulting in the amplification of the cutaneous inflammatory process (Bautista et al., 2013; Gouin et al., 2017). To further study the soothing effect of coriander seed oil, it thus could be interesting to look at the mechanisms involved in the neurogenic inflammation and to study how coriander seed oil or its main components such as petroselinic or linoleic acids could modulate them.

Whether for cosmetic and food applications, clinical data are needed to be able to conclude on the effect of coriander seed oil in humans.
Acknowledgements. Seppic would like to thank Ovalie Innovation and AGROMAT technological transfer hall of Laboratoire de Chimie Agro-industrielle (UMR 1010 INRAE/ Toulouse INP) for providing coriander seed oil.

Seppic would also like to thank Neuron Experts for having tested the coriander seed oil on the model of co-culture between keratinocytes and neurons.

\section{Conflict of interest}

Seppic has filed two patent applications based on coriander seed oil experimental results.

\section{References}

Alaluf S, Green MR, Powell JR, et al. 2002. Petroselinic acid and its use in food. U.S. Patent 6,365,175 B1.

Bamford JT, Ray S, Musekiwa A, van Gool C, Humphreys R, Ernst E. 2013. Oral evening primrose oil and borage oil for eczema. Cochrane Database Syst Rev 4: CD004416.

Bautista DM, Pellegrino M, Tsunozaki M. 2013. TRPA1: A gatekeeper for inflammation. Annu Rev Physiol 75: 181-200.

Boxman IL, Ruwhof C, Boerman OC, Löwik CW, Ponec M. 1996. Role of fibroblasts in the regulation of proinflammatory interleukin IL-1, IL-6 and IL-8 levels induced by keratinocytederived IL-1. Arch Dermatol Res 288: 391-398.

Bouic PJ. 2001. The role of phytosterols and phytosterolins in immune modulation: a review of the past 10 years. Curr Opin Clin Nutr Metab Care 4: 471-475.

Callaway J, Schwab U, Harvima I, et al. 2005. Efficacy of dietary hempseed oil in patients with atopic dermatitis. $J$ Dermatolog Treat 16: 87-94.

Duarte I, Silveira JEPS, Hafner MFS, Toyota R, Pedroso DMM. 2017. Sensitive skin: review of an ascending concept. An Bras Dermatol 92: 521-525.

Gouin O, L'Herondelle K, Lebonvallet N, et al. 2017. TRPV1 and TRPA1 in cutaneous neurogenic and chronic inflammation: proinflammatory response induced by their activation and their sensitization. Protein Cell 8: 644-661.

Gupta MB, Nath R, Srivastava N, Shanker K, Kishor K, Bhargava KP. 1980. Anti-inflammatory and antipyretic activities of betasitosterol. Planta Med 39: 157-163.

Lin TK, Zhong L, Santiago JL. 2017. Anti-inflammatory and skin barrier repair effects of topical application of some plant oils. Int $J$ Mol Sci 19: 70-91.

McCusker MM, Grant-Kels JM. 2010. Healing fats of the skin: the structural and immunologic roles of the omega- 6 and omega-3 fatty acids. Clin Dermatol 28: 440-451.

Misery L, Boussetta S, Nocera T, Perez-Cullell N, Taieb C. 2009. Sensitive skin in Europe. J Eur Acad Dermatol Venereol 23: 376381.

Misery L, Loser K, Ständer S. 2016. Sensitive skin. J Eur Acad Dermatol Venereol 30 Suppl 1: 2-8.

Misery L, Ständer S, Szepietowski JC, et al. 2017. Definition of Sensitive Skin: An Expert Position Paper from the Special Interest Group on Sensitive Skin of the International Forum for the Study of Itch. Acta Derm Venereol 97: 4-6.

Mollanazar NK, Smith PK, Yosipovitch G. 2016. Mediators of Chronic Pruritus in Atopic Dermatitis: Getting the Itch Out? Clin Rev Allergy Immunol 51: 263-292.

Moore C, Gupta R, Jordt SE, Chen Y, Liedtke WB. 2018. Regulation of Pain and Itch by TRP Channels. Neurosci Bull 34: 120-142. 
Neukam K, De Spirt S, Stahl W, et al. 2011. Supplementation of Flaxseed Oil Diminishes Skin Sensitivity and Improves Skin Barrier Function and Condition. Skin Pharmacol Physiol 24: $67-74$.

Rattanachaikunsopon P, Phumkhachorn P. 2010. Potential of coriander (Coriandrum sativum) oil as a natural antimicrobial compound in controlling Campylobacter jejuni in raw meat. Biosci Biotechnol Biochem 74: 31-35.

Reuter J, Huyke C, Casetti F, et al. 2008. Anti-inflammatory potential of a lipolotion containing coriander oil in the ultraviolet erythema test. J Dtsch Dermatol Ges 6: 847-851.

Saint-Martory C, Roguedas-Contios AM, Sibaud V, Degouy A, Schmitt AM, Misery L. 2008. Sensitive skin is not limited to the face. Br J Dermatol 158: 130-133.

Souyoul SA, Saussy KP, Lupo MP. 2018. Nutraceuticals: A Review. Dermatol Ther (Heidelb) 8: 5-16.
Ständer S, Schneider SW, Weishaupt C, Luger TA, Misery L. 2009. Putative neuronal mechanisms of sensitive skin. Exp Dermatol 18: $417-423$

Sur I, Ulvmar M, Toftgard R. 2008. The two-faced NF-kappaB in the skin. Int Rev Immunol 27: 205-223.

Uitterhaegen E, Nguyen QH, Sampaio KA, et al. 2015. Extraction of coriander oil using twin-screw extrusion: Feasibility study and potential press cake applications. J Am Oil Chem Soc 92: 12191233.

Uitterhaegen E, Sampaio KA, Delbeke EI, et al. 2016. Characterization of French coriander oil as source of petroselinic acid. Molecules 21: E1202.

Wangensteen H, Samuelsen AB, Malterud KE. 2004. Antioxidant activity in extracts from coriander. Food Chem 88: 293-297.

Wilson SR, Nelson AM, Batia L, et al. 2013. The ion channel TRPA1 is required for chronic itch. $J$ Neurosci 33: 9283-9294.

Cite this article as: Kern C, Gombert C, Roso A, Garcia C. 2020. Soothing effect of virgin coriander seed oil on sensitive skin. OCL 27: 49. 